\title{
Long Term Use of Leflunomide as a Cause of Severe Diarrhea?
}

\author{
Uzun Süreli Leflunomid Kullanımı Şiddetli Diyare Nedeni Olabilir Mi?
}

\author{
Zafer Günendi, Esin Benli, Feride Gögüşş, Fatma Atalay \\ Gazi Üniversitesi Tıp Fakültesi, Fiziksel Tıp ve Rehabilitasyon Anabilim Dalı, Ankara, Turkey
}

\section{Abstract}

Leflunomide is a recently developed disease modifying antirheumatic drug that may cause acute diarrhea as an adverse effect. This adverse effect is usually mild and develops during the first few weeks of treatment. In this report, we present a case of rheumatoid arthritis patient with severe diarrhea treated with leflunomide for an extended period of time.

(Turk J Rheumatol 2010; 25: 41-3)

Key words: Leflunomide, diarrhea, colitis

Received: 22.08 .2008

Accepted: 22.10 .2008
Özet

Leflunomid yakın zamanlarda gelișen ve yan etki olarak akut diyareye neden olabilen hastalık modifiye edici bir ilaçtır. Bu yan etki genellikle hafif șiddettedir ve tedavinin ilk haftaları sırasında gelișir. Bu yazıda, uzun süreli leflunomid tedavisi altında șiddetli diyare gelișen romatoid artritli bir olgu sunulmaktadır.

(Turk J Rheumatol 2010; 25: 41-3)

Anahtar sözcükler: Leflunomid, diyare, kolit

Alındığı Tarih: 22.08.2008

Kabul Tarihi: 22.10.2008

\section{Introduction}

Leflunomide, a recently developed disease modifying antirheumatic drug, was first reported to be effective in patients with rheumatoid athritis (RA) in 1995 (1). US Food and Drug Administration approved leflunomide for the treatment of RA in 1999 (2). Leflunomide is a prodrug and turns to its active metabolite form, A77 1726, in the intestinal mucosa and plasma. Mechanism of action of leflunomide in the treatment of RA is selectively inhibition of enzyme dihydroorotate dehydrogenase that is necessary for the de novo pyrimidine synthesis (2). Hampering of pyrimidine synthesis hinders T-cell clonal expansion (3). It has been shown that clinical efficacy of leflunomide was superior to placebo, however it was not better than methotrexate on most outcome measures $(4,5)$. The most common adverse effects of leflunomide in clinical trials were gastrointestinal symptoms, especially diarrhea. Diarrhea was usually transient and generally seen during the first few weeks of treatment $(6,7)$.

In this report, we present a patient with RA suffering from diarrhea that occurred secondary to colitis caused by long term leflunomide administration.

\section{Case Report}

46 year-old patient with rheumatoid arthritis presented with severe diarrhea causing a weight loss of 5 kg. She has been followed-up at rheumatology outpatient clinic for 14 years. She was started on methotrexate $15 \mathrm{mg} /$ week/i.m 5 years ago. 30 months ago leflunomide $20 \mathrm{mg} /$ day was added to her treatment for continuing disease activity. Four weeks before presentation she started having diarrhea. She had no history of fever or night sweats. Her stool analysis did not reveal any infective agent including bacteria and parasitic microorganisms including Entamoeba histolytica, Giardia lamblia. Gastroscopic and colonoscopic examination showed pangastritis with mucosal hyperemia and multiple colonic aphthous ulcerations (Figure 1). Pathological examination revealed focal ulceration, cryptitis, mixed inflammation at the lamina propria. However, crypt abscess, crypt distortion, granulomas and amebic organisms were not seen. In view of these findings diagnosis of drug induced colitis was made and leflunomide was stopped. Three weeks later, diarrhea was resolved. 


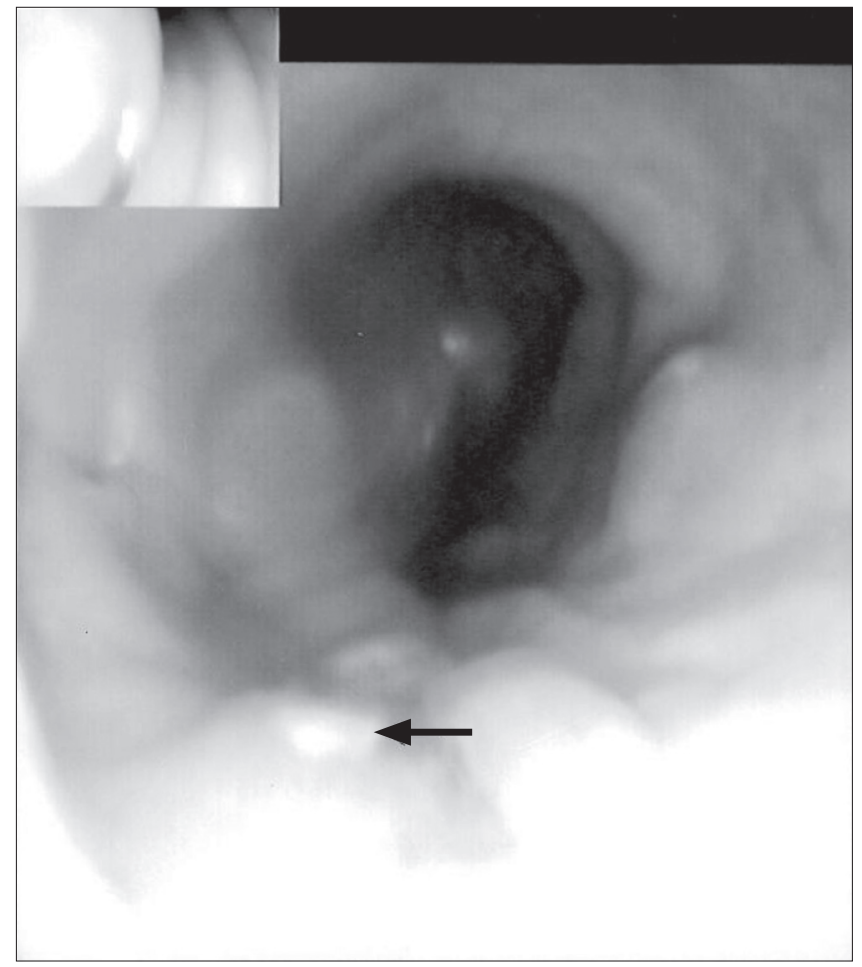

Figure 1. Colonoscopic view of aphthous ulceration in the rectosigmoidal colon (arrow)

\section{Discussion}

Diarrhea is a frequent adverse event of several drugs. More than 700 drugs have been known to cause diarrhea. Multiple mechanisms are responsible for drug induced diarrhea such as hypermotility, bacterial overgrowth secondary to hypomotility, disruption of water and electrolyte transport and mucosal damage of the small and large bowel $(8,9)$. Leflunomide is one of the drugs that may cause diarrhea as an adverse effect. Strand $V$ et al. (6) reported diarrhea in frequency of $33.5 \%$ in patients with RA treated with leflunomide. Withdrawal rate because of diarrhea was \%1.9 in leflunomide trials (10).

The major type of diarrhea associated with leflunomide is acute diarrhea, which usually appears during the first few weeks of treatment and usually transient or responds to a decrease in the dose of leflunomide (11). There is no information about the mechanism of acute diarrhea induced by leflunomide. To the best of our knowledge, two cases were reported previously with severe chronic diarrhea, lasting more than one month and appearing long time after the start of leflunomide therapy (12). One case had developed ulcerative and haemorrhagic colitis eighteen months after starting leflunomide treatment and the other case had developed microscopic colitis two years after starting treatment. Both cases had shown clinical improvements after stopping leflunomide treatment (12). In addition to these findings our case had aphthous ulcerative colitis.
Parasitic microorganisms such as Entamoeba histolytica, Giardia lamblia and some bacterial organisms including pathogenic E. Coli, Shigella sonnei, Salmonella paratyphi may cause chronic infective diarrhea (13). However microbial studies of our patient's stool regarding infective microorganisms were normal. Among antirheumatic drugs; non steroidal antiinflammatory drugs, corticosteroids and gold salts are implicated to cause colitis (14). Our patient has been on methotrexate and nonsteroidal anti inflammatory drugs for a long time. Diarrhea is also seen in patients receiving low dose methotrexate therapy. Mucosal ulcerations induced by methotrexate occur in oral region by topical effect because of secretion of this drug in saliva (15). However, methotrexate is not known to cause colonic ulceration. Furthermore methotrexate had been administrated for a much longer period of time than leflunomide. Therefore we stopped leflunomide therapy and consecutively in three weeks time diarrhea resolved. This improvement further supported the suspicion for leflunomide to be the responsible drug for colitis.

In a patient with diarrhea, the medication history is very important. Having a suspicion about a drug as a cause of diarrhea or colitis is difficult when the duration between the start of the drug and the onset of symptoms is long. In conclusion, leflunomide induced colitis should be included into the differential diagnosis of chronic diarhea in patients treated with leflunomide for an extended period of time.

\section{Conflict of Interest}

No conflict of interest is declared by the authors.

\section{References}

1. Mladenovic V, Domljan Z, Rozman B, Jajic I, Mihajlovic D, Dordevic J, et al. Safety and effectiveness of leflunomide in the treatment of patients with active rheumatoid arthritis. Results of a randomized, placebo-controlled, phase II study. Arthritis Rheum 1995; 38: 1595-603.

2. Li EK, Tam LS, Tomlinson B. Leflunomide in the treatment of rheumatoid arthritis. Clin Ther 2004; 26: 447-59.

3. Cherwinsky HM, McCarley $D$, Schatzman R, Devens $B$, Ransom JT. The immunosuppresant leflunomide inhibits lymphocyte progression through cell cycle by a novel mechanism. J Pharmacol Exp Ther 1995; 272: 460-8.

4. Osiri $M$, Shea B, Robinson V, Suarez-Almazor M, Strand V, Tugwell $P$, et al. Leflunomide for the treatment of rheumatoid arthritis: a systematic review and metaanalysis. J Rheumatol. 2003; 30: 1182-90.

5. Cohen S, Cannon GW, Schiff M, Weaver A, Fox R, Olsen N, et al. Two-year, blinded, randomized, controlled trial of treatment of active rheumatoid arthritis with leflunomide compared with methotrexate. Utilization of Leflunomide in the Treatment of Rheumatoid Arthritis Trial Investigator Group. Arthritis Rheum. 2001; 44: 1984-92.

6. Strand $V$, Cohen S, Schiff $M$, Weaver A, Fleischmann $R_{\text {, }}$ Cannon G, et al. Treatment of active rheumatoid arthritis with leflunomide compared with placebo and methotrexate. 
Leflunomide Rheumatoid Arthritis Investigators Group. Arch Intern Med. 1999; 159: 2542-50.

7. Smolen JS, Kalden JR, Scott DL, Rozman B, Kvien TK, Larsen $A$, et al. Efficacy and safety of leflunomide compared with placebo and sulphasalazine in active rheumatoid arthritis: a double-blind, randomised, multicentre trial. European Leflunomide Study Group. Lancet. 1999; 353: 259-66.

8. Ratnaike RN, Jones TE. Mechanisms of drug-induced diarrhoea in the elderly. Drugs Aging. 1998; 13: 245-53.

9. Chassany O, Michaux A, Bergmann JF. Drug-induced diarrhoea. Drug Saf. 2000; 22: 53-72.

10. Maddison P, Kiely P, Kirkham B, Lawson T, Moots R, Proudfoot $D$, et al. Leflunomide in rheumatoid arthritis: recommendations through a process of consensus. Rheumatology 2005; 44: 280-6.

11. Fox RI, Herrmann ML, Frangou CG, Wahl GM, Morris RE, Strand V, et al. Short analytical review. Mechanism of action for leflunomide in rheumatoid arthritis. Clin Immunol 1999; 93: 198-208.

12. Verschueren $P$, Vandooren AK, Westhovens R. Debilitating diarrhoea and weight loss due to colitis in two RA patients treated with leflunomide. Clin Rheumatol 2005; 24: 87-90.

13. Simadibrata $M$, Tytgat GN, Yuwono V, Daldiyono, Lesmana LA, Syam AF, et al. Microorganisms and parasites in chronic infective diarrhea. Acta Med Indones. 2004; 36: 211-4.

14. Pusztaszeri MP, Genta RM, Cryer BL. Drug-induced injury in the gastrointestinal tract: clinical and pathologic considerations. Nat Clin Pract Gastroenterol Hepatol. 2007; 4: 442-53.

15. Kalantzis A, Marshman Z, Falconer DT, Morgan PR, Odell EW. Oral effects of low-dose methotrexate treatment. Oral Surg Oral Med Oral Pathol Oral Radiol Endod. 2005; 100: 52-62. 